\title{
Degradation of fructans by epiphytic and inoculated lactic acid bacteria during ensilage of normal and sterile ryegrass
}

\author{
RJ Merry ${ }^{1}$, AL Winters ${ }^{1}$, PI Thomas ${ }^{1}$, M Müller 2, T Müller ${ }^{2}$ \\ IInstitute of Grassland and Environmental Research (IGER), Plas Gogerddan, Aberystwyth, Dyfed SY23 3EB, \\ UK ; ${ }^{2}$ Centre for Agricultural Landscape and Land Use Research Münchenberg, Institute of Microbial \\ Ecology, Gutshof 7, 14641, Paulinenaue, Germany
}

It is generally accepted that the entire water soluble carbohydrate (WSC) fraction of grasses is readily available for fermentation in the silo by lactic acid bacteria (LAB) and other silage bacteria. This includes the polymer fructan which can be a major component of the WSC fraction of temperate grasses. However, recently it was suggested that the majority of $\mathrm{LAB}$ on grasses may not possess fructan hydrolase activity (Müller and Lier, 1994, J Appl Bact 76, 406-411), which has implications for their effective ensilage.

Ryegrass was ensiled either untreated (control), or after irradiation (sterile), or sterile and inoculated $\left(10^{6} \mathrm{CFU} / \mathrm{g} \mathrm{FM}\right)$ with either Lactobacillus paracasei ssp paracasei ${ }^{+}$or Lactobacillus plantarum - ${ }^{-}$. The former bacterium (+) has been shown to possess, and the latter (-) to lack ability to degrade grass fructans. Grasses were ensiled at $23^{\circ} \mathrm{C}$, sampled at intervals up to $90 \mathrm{~d}$ and analysed for $\mathrm{pH}$ and fructan content.

Fructans were separated by HPLC and carbohydrate mass determined by differential refractometry and peak area integration. Dry matters of herbages and silages were determined by freeze drying.
Fructan breakdown observed in sterile herbage indicated that grass fructan hydrolases were active throughout the fermentation period at the relatively constant $\mathrm{pH}$ value of 6 . Plant enzyme activity probably also accounted for some fructan breakdown in the $L$. plantarum inoculated silage, but the rate of degradation slowed after $4 \mathrm{~d}$ when the $\mathrm{pH}$ had declined below 4 . In both control and L.paracasei ${ }^{+}$ inoculated silages there was a significantly higher rate of fructan degradation, suggesting the involvement of microbial enzymes, coupled with an indeterminate contribution from plant enzyme activity.

The results do not completely resolve the question of whether microbial fructan hydrolase activity, particularly in lactic acid bacteria, is a prerequisite for rapid fermentation, but suggest that in herbages where it is low and fructan content high, availability of WSC could be compromised. This may be critical for the ensilage of late season, low sugar crops and indicates that a silage inoculant strain possessing enzymes active against plant fructans may be beneficial under such conditions
Time (d)

Control

Sterile

L. paracasei ${ }^{+}$

L. plantarum ${ }^{-}$
0

77.8

76.0

76.0

76.0
2

Fructan concentration (g/kg DM)

48.2

60.4

45.3

71.4

23.8
52.7
24.0
48.6

23.8

24.0

48.6
14

8.1
11.9
9.6
29.5

90

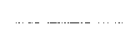

2.9

6.9

5.4

14.7 